\title{
Norovirus, the principal cause of viral diarrhea in two regions of Colombia
}

\author{
Fernández KP ${ }^{1}$, Ulloa JC ${ }^{1}$, Meneses $\mathrm{M}^{1}$, Matiz $\mathrm{LF}^{1}$, Gutiérrez $\mathrm{MF}^{1 凶}$
}

\begin{abstract}
Rotavirus is recognized worldwide as the main and most important viral pathogen associated with diarrhea in children while norovirus is considered the second cause of epidemic diarrhea in developed countries. Here, we present a comparative study on the prevalence of rotavirus and norovirus in two regions of Colombia: Chocó and Cundinamarca. Five hundred and thirty stool samples were collected; 330 in Cundinamarca and 200 in Chocó. In the sample set from Chocó, $6 \%$ of the samples presented rotavirus and $8 \%$ norovirus; meanwhile, $9.7 \%$ of the samples from Bogotá presented rotavirus and $9 \%$ norovirus. These results show that, in some regions of Colombia, the prevalence of norovirus is similar or slightly higher than rotavirus. This is a tendency that should be examined in other non-developed countries as it suggests that the presence of norovirus should also be under surveillance.
\end{abstract}

Keywords: Norovirus; Rotavirus; diarrhea; Chocó; Cundinamarca.

Edited by Alberto Acosta $\square$

1. Laboratorio de Virología, Universidad Javeriana, Bogotá, Colombia

Received: 14-05-2014 Accepted: 05-08-2014

Published on line: 29-09-2014

Citation: Fernández KP, Ulloa JC, Meneses M, Matiz LF, Gutiérrez MF (2015) Norovirus, the principal cause of viral diarrhea in two regions of Colombia. Universitas Scientiarum 20(1): 107-115

doi: 10.11144/Javeriana.SC20-1.npcv

Funding: Banco de la República.

Electronic supplementary material: Suppl. 1.

\section{Introduction}

Rotaviruses (RV) are non-enveloped virions, with an 11-segmented dsRNA and a triple layer concentric protein capsid. Norovirus (NV), meanwhile, is positive RNA strand, non-enveloped as well and singled capsid virus (Guerrero et al. 2000, Hardy 2005). Diarrhea is considered the second leading cause of deaths in children under 5 years old and enteric viruses are the most important etiological agents of acute diarrhea disease (ADD) in children all around the world. Within these, the Group A of Rotavirus (RV) has been recognized as the most prevalent, but other viruses such as astrovirus, enteric adenovirus and norovirus (NV), have also been reported (Wilhelmi et al. 2003, Meraabi et al. 2011). 
$\mathrm{NV}$ is known to be associated with epidemic behaviors affecting people in developed countries dwelling crowded places such as schools, nursing homes, military centers, but in developing countries the same virus has been associated with sporadic diarrhea (Wu et al. 2008, Donaldson et al. 2008, Harris et al. 2010, Wiegering et al. 2011). Therefore, NV has been considered the most important cause of epidemic gastroenteritis, the second most important cause of endemic gastroenteritis in all age groups worldwide and a common cause of sporadic nonbacterial gastroenteritis in individuals of all ages. The overall clinical burden caused by NV infection is thought to be milder than the one given by RV (Beersma et al. 2009, Yanga et al. 2010) because RV infections are known to be more severe and more often associated with a complicated course (Donaldson et al. 2008, Ciarlet \& Schödel 2009, Lin et al. 2010, Meraabi et al. 2011, Rivera et al. 2011, Wiegering et al. 2011, Solano-Aguilar et al. 2012)

One of the main reasons of the important prevalence of those viruses is their route of infection. The fecal-oral route is the common route of transmission, typically through food, water or contaminated surfaces; but person-to-person transmission, by direct contact or exposure to aerosols from vomit, are also important (Wilhelmi et al. 2003, Wu et al. 2008, Ribes \& Buesa 2010, Wiegering et al. 2011, Lopman et al. 2012). High concentrations of these viral agents are introduced into the environment through the discharge of either treated or untreated sewage (Lin et al. 2010, Blanco et al. 2012).

In Colombia, our group has performed for over 10 years, two studies looking for viral agents associated with ADD. In both, prevalence's of NV were similar to RVs. In the year 2000, we tested 300 diarrheic stool samples and found $10 \%$ of NV and $13 \%$ of RV in children with less than 5 years of age in FacatativáCundinamarca, Colombia (Gutierrez et al. 2006). Later in 2003, we found $8 \%$ and $10 \%$ for RV and NV respectively in fecal samples of children coming from Quibdó, Chocó. Therefore, the prevalence of NV could outperform the well-known prevalence of RV. In order to show that $\mathrm{NV}$ is associated with sporadic and endemic diarrhea and exhibits a behavior which may be even greater than RVs in children, new set of samples were collected from the same Colombian regions: Cundinamarca and Chocó.
The aim of this study was to evaluate the presence of RV and NV in a new set of samples collected from the regions already described.

\section{Material and methods}

\section{Sample collection}

A total of 530 children under 5 years of age from two Colombian regions (one located in Bogotá, Cundinamarca, capital of Colombia and the other one in Quibdó, a small city of Chocó, close to the pacific coast in the northwest area of the country) were recruited to participate in a prospective, observational study. For the inclusion of the children in the diarrhea group the subjects must meet the criteria stated by the World Health Organization (WHO) for diarrhea as liquid or reduced consistency of the stool with an increased frequency of $>3$ times in $24 \mathrm{~h}$ for a period of less than 2 weeks. Healthy children, from the same locations, were those without any clinical signs of diarrhea disease, vomiting or fever and with normal stool consistency before the beginning of the study. After obtaining informed parental consent, stool specimens and demographic information (including age, gender and RV vaccine) were collected. Fecal samples were collected, immediately refrigerated at $4{ }^{\circ} \mathrm{C}$ and transported to the Virology Laboratory at the Pontificia Universidad Javeriana. Upon receipt, samples were separated in two aliquots. One aliquot was conserved at $-80^{\circ} \mathrm{C}$ and the other one was used for the RNA extraction and subsequent viral identification.

\section{Viral detection}

RV and NV were detected by conventional RT-PCR. Initially, viral RNA was extracted from $10 \%$ stool suspension in PBS by the use of QIAamp ${ }^{\circledR}$ Viral RNA Mini kit (Qiagen, Courtaboeuf, France) according to the instructions provided by the manufacturer. Then, for the retrotranscription step, five microliters of RNA were mixed with 1 pmol of antisense primer incubated at $95^{\circ} \mathrm{C} \times 5$ min and chilled immediately on ice. A mixture of Buffer 5x-RT, DTT 0.1 M, dNTP's (10 mM), Superscript III (Invitrogen,Corporation, Carlsbad, CA, USA ) and RNase-free water was added to yield a final volume of $20 \mu \mathrm{l}$ reaction. The tubes were incubated to $50{ }^{\circ} \mathrm{C}$ for 1 hour and then at $70{ }^{\circ} \mathrm{C}$ for $15 \mathrm{~min}$ for enzymatic inactivation. 
For the PCR, specific primers against viral capsid of NV (Richards et al. 2004) and the structural viral glycoprotein of RV (Gouvea et al. 1990) previously reported were used. Positive diluted controls and unknown samples were included in the RT-PCR with the conditions previously described.

The PCR products were separated by electrophoresis in $2 \%$ agarose gel and visualized under UV lamp after ethidium bromide staining. Neither RV nor NV was genotyped.

\section{Statistical analysis}

Four parameters were considered: diarrhea, age, gender and vaccination against the $R V$. Two different statistical analyses were performed with the SPSS program for Windows. 1) A descriptive analysis in order to show the frequency of each virus, and 2) A bivariate analysis in order to make clear the relationship between virus and risk factors like age, gender and vaccination. For this, $2 \times 2$ tables were built; Odds ratio, $\mathrm{p}$ value and Confidence interval (IC) were obtained. A p value $<0.05$ was considered statistically significant.

\section{Results}

A total of 530 stool samples was collected from two different regions in Colombia, 330 of them came from Bogotá- Cundinamarca and 200 from Chocó. From this, 279 were from boys (180 from Bogotá-Cundinamarca and 99 from Chocó) and 251 for girls (151 from Bogotá- Cundinamarca and 100 from Chocó). From each region, half of the samples (265) were taken from healthy children and the other half (265) of infants suffering from diarrhea; it means that 165 children from Bogotá were healthy and 165 ill, while 100 children from Quibdó were healthy and 100 were children with diarrhea. RV and NV were detected in $29(5.5 \%)$ and 28 $(5 \%)$ out of 530 stool specimens collected, respectively.

RV was found in 22/265 (8.3\%) diarrheal samples and in 7 non-diarrheal samples $(2.7 \%) \mathrm{NV}$ was found in $23 / 265(8.7 \%)$ diarrheal samples and in $5(1.9 \%)$ non-diarrheal samples (Table 1). Co infection between RV and NV was found in only one boy of 24 months old from Quibdó.

Related to the age of the children, all of them were under 5 years old. In diarrheic stool samples from Bogotá, a total of 16 rotavirus positive cases were found, with a
Table 1. Positive cases/total cases and percentage (\%) of rotavirus and norovirus in children under five years old in two different regions of Colombia detected by RT-PCR.

Diarrhea

Non diarrhea

Total

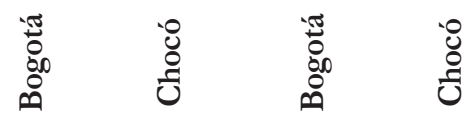

\begin{tabular}{|c|c|c|c|c|c|}
\hline$\stackrel{n}{z}$ & $16 / 165$ & $6 / 100$ & $7 / 165$ & $0 / 100$ & $29 / 530$ \\
\hline בิ & $(9.7 \%)$ & $(6 \%)$ & $(4.2 \%)$ & & $(5.5 \%)$ \\
\hline$\stackrel{n}{z}$ & $15 / 165$ & $8 / 100$ & $5 / 165$ & $0 / 100$ & $28 / 530$ \\
\hline$z$ & $(9 \%)$ & $(8 \%)$ & $(3 \%)$ & & $(5 \%)$ \\
\hline
\end{tabular}

greater presence in children between 7 and 48 months. In Chocó, RV was found in children between 0 to 36 months with no positive cases in the ages of 37 to 60 months. For $\mathrm{NV}$ in Bogotá a total of 15 positive cases were reported between 7 and 60 months. In Chocó, this same pathogen was found in a total of 8 children from 4-60 months. No statistical analysis was performed on these data.

In order to compare the prevalence of both viruses in both regions related to the age of the children, cumulated frequency table were obtained. Figure 1 shows the cumulated frequency of these viruses in children with diarrhea.

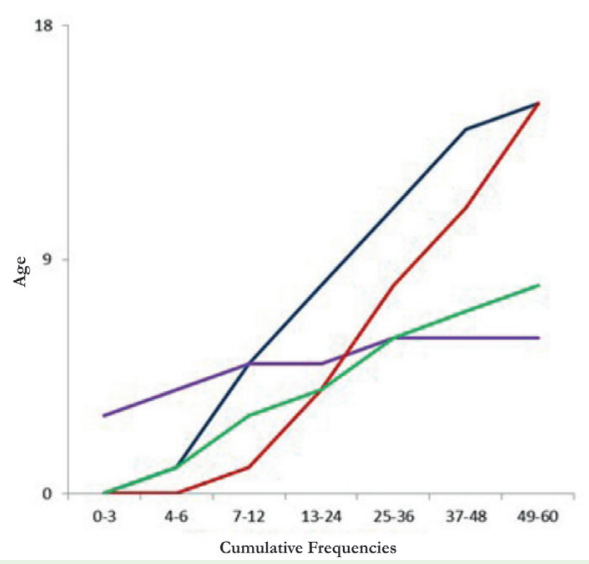

Fig. 1. Cumulated frequency of viral infection produced by $\mathrm{RV}$ or NV in children from Bogotá and Chocó between January and December of 2009. Blue line: RV in Bogotá. Red line: NV in Bogotá. Purple line: RV in Chocó. Green line: NV in Chocó. $\mathrm{X}$ axis is the age in months and $\mathrm{Y}$ axis is the cumulative frequencies. 
Table 2. Presence of RV in vaccinated and non-vaccinated children against RV.

\begin{tabular}{lcccccc}
\hline $\begin{array}{l}\text { Vaccine Against } \\
\text { Rotavirus }\end{array}$ & $\begin{array}{c}\text { Children Without } \\
\text { Diarrhea, Bogotá }\end{array}$ & $\begin{array}{c}\text { RV } \\
+\end{array}$ & $\begin{array}{c}\text { Children With } \\
\text { Diarrhea, Bogotá }\end{array}$ & $\begin{array}{c}\text { RV } \\
+\end{array}$ & $\begin{array}{c}\text { Children with } \\
\text { diarrhea in Chocó }\end{array}$ & $\begin{array}{c}\text { RV } \\
+\end{array}$ \\
\hline One dose & 12 & 0 & 35 & 1 & 0 & 0 \\
Two doses & 34 & 2 & 20 & 1 & 9 & 0 \\
None & 62 & 2 & 73 & 8 & 69 & 6 \\
No information & 57 & 3 & 37 & 6 & 22 & 0 \\
Total & 165 & 7 & 165 & 16 & 100 & $\mathbf{6}$ \\
\hline
\end{tabular}

Of the 530 children enrolled, only 110 (20.7\%) were RV vaccinated. The usefulness of the vaccine against RV is shown in Table 2 . It is important to remark that 2 children, who were vaccinated twice,

Table 3. Bivariate analysis to clarify the relationship between pathogen and risk factors. OR: Odds ratio, IC: Confidence interval, p: $p$ value; ind: non defined.

\begin{tabular}{|c|c|c|c|c|c|}
\hline & & Bogotá & Bogotá & Chocó & Chocó \\
\hline & & RV & NV & RV & NV \\
\hline \multirow[t]{3}{*}{ Diarrhea } & Yes/No & OR: 2.42 & OR: 3.2 & ind & ind \\
\hline & & IC: 0.96-6.05 & IC: $1.13-9.02$ & & \\
\hline & & p: 0.023 & p: 0.037 & & \\
\hline Age & $0-24$ & OR: 0.7 & OR: 0.42 & ind & OR: 0.22 \\
\hline \multirow[t]{2}{*}{ (months) } & $25-60$ & IC: $0.28-1.77$ & IC: $0.14-1.22$ & & IC: $0.5-0.99$ \\
\hline & & p: 0.61 & p: 0.16 & & p: 0.033 \\
\hline \multirow[t]{3}{*}{ Gender } & Female/ & OR: 0.74 & OR: 0.42 & OR: 2.08 & OR: 1.02 \\
\hline & male & IC: $0.32-1.74$ & IC: 0.16-1.09 & IC: $0.37-11$ & IC: $0.25-4.2$ \\
\hline & & p: 0.64 & p: 0.11 & p: 0.66 & p: 1 \\
\hline
\end{tabular}


had RV but they don't suffer from diarrhea. Besides, 2 children whom received only one dose of vaccine and another one who received two doses, also had RV but they do suffer from diarrhea. From the vaccinated people, $3.6 \%$ had RV and $1.8 \%$ had also diarrhea. This study did not intend to evaluate the efficacy of the vaccine; it just wanted to see the presence of the virus in those whose said were vaccinated.

Bivariate analysis was made in order to show if the relationship between virus, diarrhea, age and gender had statistical significance. Children with NV has 3, 2 more possibilities to have ADD than children without $\mathrm{NV}$ with $\mathrm{p}=0.037$. None other result showed statistical significance (Table 3).

The next bivariate analysis was made in order to see if vaccination against RV had a protector effect. The results showed no relation between rotavirus vaccine and diarrhea (Table 4).

\section{Discusion}

According to several studies RV seems to remain the most prevalent viral pathogen around the world (Manrique et al. 2006, Ciarlet \& Schödel 2009). Surprisingly, in non-developed countries, the prevalence of NV could be similar or even greater than the RV. For instance, in this study both viruses showed very similar prevalence's, but if we compare RV with NV in Chocó, theirprevalence's were $6 \%$ for $\mathrm{RV}$ and $8 \%$ for NV. The same behavior was reported 5 years ago when we found prevalence's of 8 and $10 \%$ for the same viruses in the same type of population and with the same detection method at that time, we reported NV as a new finding (Martínez et al. 2005) but now, we can suppose that $\mathrm{NV}$ is present all the time in our population and this virus could be more frequent than expected.

In this study, we reported prevalence's of both viruses lower than the reported in other places of

Table 4. Bivariate analysis to clarify the effectiveness of the RV vaccine in these populations. Ind: indeterminate. There is no significant statistical correlation between vaccinated subjects and diarrhea or no diarrhea.

\begin{tabular}{|c|c|c|c|c|c|}
\hline & & Diarrhea & Chocó & Bogotá & Chocó \\
\hline & & Non diarrhea & Non diarrhea & Diarrhea & \\
\hline \multirow{3}{*}{$\begin{array}{l}\text { Vaccination } \\
\text { against RV }\end{array}$} & \multirow{3}{*}{$\begin{array}{l}1 \text { or } 2 \text { doses/ } \\
\text { No vaccine }\end{array}$} & OR: 1.34 & & OR: 0.33 & \\
\hline & & IC: $0.18-9.92$ & ind & IC: $0.06-1.62$ & ind \\
\hline & & p: 0.76 & & $\mathrm{p}: 0.15$ & \\
\hline \multirow{3}{*}{$\begin{array}{l}\text { Vaccination } \\
\text { against RV }\end{array}$} & \multirow{3}{*}{$\begin{array}{l}1 \text { or } 2 \text { doses/no } \\
\text { information or no } \\
\text { vaccinated }\end{array}$} & OR: 1.03 & \multirow{3}{*}{ ind } & OR: 0.28 & OR: 0.46 \\
\hline & & IC: $0.19-5.52$ & & IC: $0.06-1.30$ & IC: 0.05-4.16 \\
\hline & & p: 0.96 & & p: 0.086 & p: 0.48 \\
\hline
\end{tabular}


the world, but we found consistent results with previous reports for RV in Colombia. In Tunisia, RV and NV were detected in $22.5 \%$ and $17 \%$ of the fecal samples collected from children with acute diarrhea (Meraabi et al. 2011), in Saudi Arabia 50 \% of gastroenteritis cases were associated with virus infection, the RV was more prevalent in patients, followed by adenovirus, NV and astrovirus (Meraabi et al. 2011) and in Brazil, RV was associated with $12-42 \%$ of hospitalized acute cases of diarrhea in children (Strinaa et al. 2012). In Yanga et al. 2010 study, NV was detected in $14.6 \%$ and RV in $20.2 \%$ of all fecal samples. In Colombia, $24.8 \%$ percent of RV was found in Cartagena and $18.0 \%$ in Facatativa (Gutierrez et al. 2005).

Even though, some studies show results like ours. For example in another study in Taiwan, NV was present in $10.9 \%$ of all specimens tested. This percentage is similar to that found in previous studies, in which NV was founded in $6.5-18 \%$ of all cases of gastroenteritis (Wu et al. 2008). These results indicated that $\mathrm{NV}$ was a major viral pathogen, after rotavirus, in younger children hospitalized with acute diarrhea. In Brazil showed the increase in the incidence of NV infection, from 17.3-29.0 $\%$. This may be because current testing methods were more sensitive; the incidence of NV detection nearly doubled when enzyme immunoassays were combined with the more sensitive RT-PCR, as previously proposed by Wu et al in 2008 (Yanga et al. 2010).

It is important to remark that RV is associated with severe gastroenteritis. Since NV infection tend to be mild, and the serious gastroenteritis patients tend to be handled by the specialists within gastroenterology or infectious diseases, the high prevalence of NV infection may have been underestimated (Manrique et al. 2006, Donaldson et al. 2008, Lin et al. 2010, Ribes \& Buesa 2010, Yanga et al. 2010, Wiegering et al. 2011).

In this study, RV and NV infections do not seem to show any relation to age and gender even when most studies consistently demonstrating that RV mainly affects younger children less than 5 years and the proportion of RV infections among younger children was higher than that in the older age groups (Yanga et al. 2010, Wiegering et al. 2011). The general belief is that NV is a major pathogen leading to diarrheal outbreaks and causes symptomatic infections in older children and adults (Yanga et al. 2010). Our results showed a slightly different about the time that ADD started. In RV, the first children with diarrhea had between 0 to 3 months old and in NV had 4-6 months old. Then, it seems that NV also has an impact on children younger than 24 months. There was nonstatistic significance when the age of infections was compared between 0-24 to $25-60$ months of age. Comparing the behavior between 0-24 to 25-60 months of age, non-statistic significance was found. This means that those viruses infect the same children population from 0 to 24 than for 25 to 60 . No gender predisposition was found.

The presence of $4 \%$ and $3 \%$ of RV and NV in Bogotá in children without diarrhea is an important finding. It is known that RV vaccine do not avoid the infection, it just seems to decrease the symptoms, therefore it is possible to find cases with RV positive, and ADD negative. With NV, there is not vaccine (Harris et al. 2010), therefore, $3 \%$ of NV in children without diarrhea it seems that they can act as healthy carrier.

For rotavirus, research has progressed, and simple, sensitive, and inexpensive immunoassays are used as the diagnostic test of choice available in laboratories around the world. On the basis of assay results, rotavirus was determined to be the most common cause of severe diarrhea in children worldwide. By contrast, the other enteric viruses, could not be detected as easy as this virus (Glass 2013).

Timely monitoring of norovirus activity has remained elusive in part because of the scarcity of diagnostic testing for patients with suspected disease. In USA, approximately $90 \%$ of persons with acute viral gastroenteritis do not seek medical attention; of those who do, only $6 \%$ submit stool specimens for diagnostic testing, in part because testing is often not deemed necessary for selflimited illness (Rha et al. 2013). 
In our country, it seems similar. Even though we can find an ELISA kit to test this virus in stool samples, it is expensive and there is no awareness of its medical impact in our population

\section{Conclusion}

Ourstudy demonstrated that there is an underestimated prevalence of Norovirus in Colombia that it has to be taken into consideration. Even though RV still is one of the most important viral agents responsible for ADD, it is important to take a better surveillance for NV.

\section{Acknowledgments}

We want to especially acknowledge the Bank of the Republic for financing the project and all the students who somehow contributed to the development of this work.

\section{Conflict of interest}

Potential conflict of interest none reported.

\section{References}

Beersma M, Schutten M, Vennema H, Hartwig N, Mes T, Osterhaus A, Koopmans M (2009) Norovirus in a Dutch tertiary care hospital (2002 e 2007): frequent nosocomial transmission and dominance of GIIb strains in young children. Journal of Hospital Infection (71): 199-205 doi: 10.1016/j.jhin.2008.11.018

Blanco M, Torres C, Poma H, Riviello-López G, Martínez L, Cisterna D, Mbayed V (2012) Environmental surveillance of norovirus in Argentina revealed distinct viral diversity patterns, seasonality and spatio-temporal diffusion processes. Science of the Total Environment (437): 262-269 doi: 10.1016/j. scitotenv.2012.08.033

Ciarlet M \& Schödel F (2009) Development of a rotavirus vaccine: Clinical safety, immunogenicity, and efficacy of the pentavalent rotavirus vaccine, RotaTeq ${ }^{\circledR}$. Vaccine (275): 72-81 doi: 10.1016/j. vaccine.2009.09.107
Donaldson E, Lindesmith L, Lobue A, Baric R (2008) Norovirus pathogenesis: mechanisms of persistence and immune evasion in human populations. Immunological Reviews (225): 190-211 doi: 10.1111/j.1600-065X.2008.00680.x

Glass R (2013) Beyond Discovering the Viral Agents of Acute Gastroenteritis. Emerging infectious disease 19:(8) 1990-1991 doi: 10.3201/eid1908.130773

Gouvea V, Glass RI, Woods P, Taniguchi K, Clark HF, Forrester B, Fang ZY (1990) Polymerase chain reaction amplification and typing of rotavirus nucleic acid from stool specimens. J Clin Microbiol 28(2): 276-282

Guerrero CA, Zarate S, Corkidi G, Lopez S, Arias CF (2000) Biochemical characterization of rotavirus receptors in MA104 cells. [Research Support, NonU.S. Gov't]. J Virol 74(20): 9362-9371

Gutierrez MF, Matiz A, Trespalacios A, Parra M, Riaño M, Mercado M (2006) Virus diversity of acute diarrhea in tropical highlands. Rev latinoam. Microbiol. 48(1): 17-23

Gutiérrez MF, Urbina D, Matiz A, Puello M, Mercado M, Parra M, Ajami N, Serrano P, Trespalacios AA (2005) Comportamiento de la diarrea causada por virus y bacterias en regiones cercanas a la zona ecuatorial. Colombia Médica 36 (4) 6-14

Hardy ME (2005) Norovirus protein structure and function. [Research Support, N.I.H., Extramural Research Support, U.S. Gov't, Non-P.H.S. Review]. FEMS Microbiol Lett 253(1):1-8

Harris J, Lopman B, O'Brien S (2010) Infection control measures for norovirus:a systematic review of outbreaks in semi-enclosed settings. Journal of Hospital Infection (74): 1-9 doi: 10.1016/j. jhin.2009.07.025

Lin C, Chiua N, Leea H, Chuangb C, Lin S, Yeunga C (2010) The Emerging Importance of Norovirus as the Etiology of Pediatric Gastroenteritis in Taipei. Journal of Microbiology, Immunology and Infection 43(2):105-110 doi: 10.1016/S16841182(10)60017-5

Lopman B, Gastañaduy P, Woo G, Hall A, Parashar U, Vinje J (2012). Environmental transmission of norovirus gastroenteritis. Current Opinion in Virology 2 (1): 96-102 doi: 10.1016/j.coviro.2011.11.005 
Manrique F, Billon D, Bello S, Ospina J (2006) Agentes causales de diarrea en niños menores de 5 años en Tunja, Colombia. Rev. salud pública 8(1): 88-97

Martínez L, Matiz A, Trespalacios A, Ajami N, Mora C, Serrano P, Gutiérrez M (2005) Etiología de la enfermedad diarreica aguda en niños menores de 5 años en la población de Quibdó. El Calicivirus, un nuevo hallazgo. Pediatría 40(1): 43-52

Meraabi R, Chehadehb W, Hamzea M, Dabboussia F, Hlais S, Mallat H (2011) First description of gastroenteritis viruses in Lebanese children: A pilot study. Journal of infection and public health (4): 59-64 doi: 10.1016/j.jiph.2011.01.002

Rha B, Burrer S, Park S, Trivedi T, Parashar U, Lopman B (2013) Emergency Department Visit Data for Rapid Detection and Monitoring of Norovirus Activity, United States. Emerging infectious disease 19:(8) 1214-1221

Ribes J \& Buesa J (2010) Infecciones por norovirus. Enfermedades Infecciosas y Microbiología Clínica 28(1): 51-55

Richards GP, Watson MA, Fankhauser RL, Monroe SS (2004) Genogroup I and II noroviruses detected in stool samples by real-time reverse transcription-PCR using highly degenerate universal primers [Evaluation Studies]. Appl Environ Microbiol 70(12): 7179-7184 doi: 10.1128/AEM.70.12.7179-7184.2004

Rivera F, Ochoa T, Ruiz J, Medina A, Eckere L, Mercado E, Lanatae C (2011) Norovirus prevalence in 'pathogen negative' gastroenteritis in children from periurban areas in Lima, Perú. Transactions of the Royal Society of Tropical Medicine and Hygiene (105): 734-736 doi: 10.1016/j.trstmh.2011.08.009

Solano-Aguilar G, Fernandez K, Ets H, Molokin A, Vinyard B, Urban J, Gutierrez MF (2012) Characterization of intestinal microbiota of children with diarrhea in two tropical highland locations in Colombia South America. Journal of Pediatric Gastroenterology \& Nutrition 56(5) 503-511 doi: 10.1097/MPG.0b013e318282aa12

Strinaa A, Rodrigues L, Cairncrossc S, Ferrera S, Fialhoe A, Leite J, Barretoa M (2012) Factors associated with rotavirus diarrhoea in children living in a socially diverse urban centre in Brazil. Transactions of the Royal Society of Tropical Medicine and Hygiene (106): 445-451 doi: 10.1016/j.trstmh.2012.02.001
Wiegering V, Kaiser J, Tappe D, Weißbrich B, Morbach H, Girschick H (2011)Gastroenteritis in childhood: a retrospective study of 650 hospitalized pediatric patients. International Journal of Infectious Diseases (15): 401-407 doi: 10.1016/j.ijid.2011.02.006

Wilhelmi I, Roman E, Sanchez-Fauquier A (2003) Viruses causing gastroenteritis. Clin Microbiol Infect (9): 247-262

Wu T, Liu H, Chen Y, Tang R, Hwang B, Yuan H (2008) Comparison of Clinical Features of Childhood Norovirus and Rotavirus Gastroenteritis in Taiwan. J Chin Med Assoc 71(11): 566-570 doi: 10.1016/S17264901(08)70170-9

Yanga S, Hwanga K, Wuc F, Wuc S, Hsiungc C, Changd W, Huangf Y (2010) Epidemiology and Clinical Peculiarities of Norovirus and Rotavirus Infection in Hospitalized Young Children with Acute Diarrhea in Taiwan 2009. Journal of Microbiology, Immunology and Infection 43(6): 506-512 doi: 10.1016/S16841182(10)60078-3 
Norovirus, la principal causa de diarrea en dos regiones de Colombia

Resumen. El rotavirus es conocido como el primer y más importante patógeno viral asociado con la diarrea en los niños de todo el mundo. Norovirus se ha considerado como otra de las causas de la diarrea relacionada con su comportamiento emergente en los países desarrollados. En este trabajo se presenta un estudio comparativo en relación con la prevalencia de la NV y RV en dos regiones de Colombia: Chocó y Cundinamarca. Se recogieron 530 muestras de heces, 330 corresponden a la ciudad de Bogotá-Cundinamarca y 200 al departamento de Chocó. RV fue encontrado en un 6 $\%$ mientras NV en un $8 \%$ en las muestras procedentes de Choco. En Bogotá, RV tuvo una prevalencia ligeramente más alta que NV $9.7 \%$ y $9 \%$ respectivamente Este resultado muestra que en los países no desarrollados, la prevalencia de la NV podría ser similar o incluso superior a la RV, por lo tanto, la presencia de NV debe tener más vigilancia.

Palabras clave: Norovirus; Rotavirus; diarrea; Chocó; Cundinamarca.
Norovírus, a principal causa de diarréia viral em duas regiôes da Colômbia

Resumo. O rotavírus tem sido conhecido como o primeiro eo mais importante patógeno viral associada com diarréia em crianças em todo o mundo e. Norovírus tem sido considerada como uma outra causa de diarreia relacionada com o comportamento epidemia em países desenvolvidos. Neste artigo vamos mostrar um estudo comparativo relacionado à prevalência de $\mathrm{NV}$ e RV em duas regiões da Colômbia: Chocó e Cundinamarca. Um total de 530 amostras de fezes foram coletadas, das quais 330 correspondem a partir de Bogotá-Cundinamarca e 200 de Chocó. A RV foi encontrada em 6 \% no de amostras de Chocó enquanto NV foi encontrado em $8 \%$ no mesmo conjunto de amostras. Em Bogotá, RV foi menosprezado uphigher de NV, mostrando prevaleces de $9.7 \%$ para RV e $9 \%$ para a NV. Este resultado mostra que em países não desenvolvidos, a prevalência da NV poderia ser semelhante ou até maior do que a RV, portanto, a presença de NV deve ser ter mais vigilância.

Palavras-chave: Norovírus; Rotavírus; diarréia; Chocó; Cundinamarca. 